\title{
The Influence of Hydrography on the Distribution of Phytoplankton in the Southern Taiwan Strait
}

\author{
R. Huang \\ Institute of Oceanography, National Taizwan University, Taipei, Taizan, \\ Republic of China
}

Received 9 September 1987 and in revised form 16 February 1988

\begin{abstract}
Keywords: phytoplankton; distribution; hydrographic; statistical analysis; tracers; Taiwan Strait

During the period August 1985 to May 1986, phytoplankton in the southern Taiwan Strait was collected and studied for distributional variability in relation to hydrography. The results indicated that maximum standing crops of phytoplankton occurred in October and May due to the outgrowth of certain species of diatoms and blue-green algae. The majority of phytoplankton appeared in the water in the top $25 \mathrm{~m}$ and occurred in distinct clusters under the influence of water movement. Multivariate analysis indicated that hydrographic parameters, which accounted for the variability of phytoplankton distribution, varied seasonally. Vertical, spatial and temporal variabilities were also apparent. The close relationship between hydrography and algal distribution justifies the use of variations in the phytoplankton population as a useful tracer of water movement.
\end{abstract}

\section{Introduction}

In an aquatic system, phytoplankton distribution is linked to the biotic and abiotic characteristics of the water. Phytoplankton may grow rapidly and demonstrate various responses to the environment in which they grow, resulting in high spatial heterogeneity. However, the source of variability is not easily discernible. Multivariate statistical analysis has been employed for this purpose in a few studies. Estrada and Blasco (1979), Blasco et al. (1980), Estrada (1984) and Matta and Marshall (1984) used principal-component analysis to relate upwelling processes to phytoplankton distribution. Holligan et al. (1980) and Maddock et al. (1981) used the correspondence analysis in dealing with dinoflagellates around the British Isles, whilst Moll and Rohlf (1984) combined multivariate and univariate analyses for salt marsh phytoplankton. All these studies demonstrated that multivariate analysis techniques are powerful tools for quantifying relationships between phytoplankton populations and their environment.

The hydrography of the southern Taiwan Strait has been intensively studied (e.g. Chu, 1963; Fan, 1982; Hung et al., 1986). Three major currents flow over the south strait with very different features. The warm South China Sea Current moves northward into the strait when the south-west monsoon wind prevails in summer. During this period a 


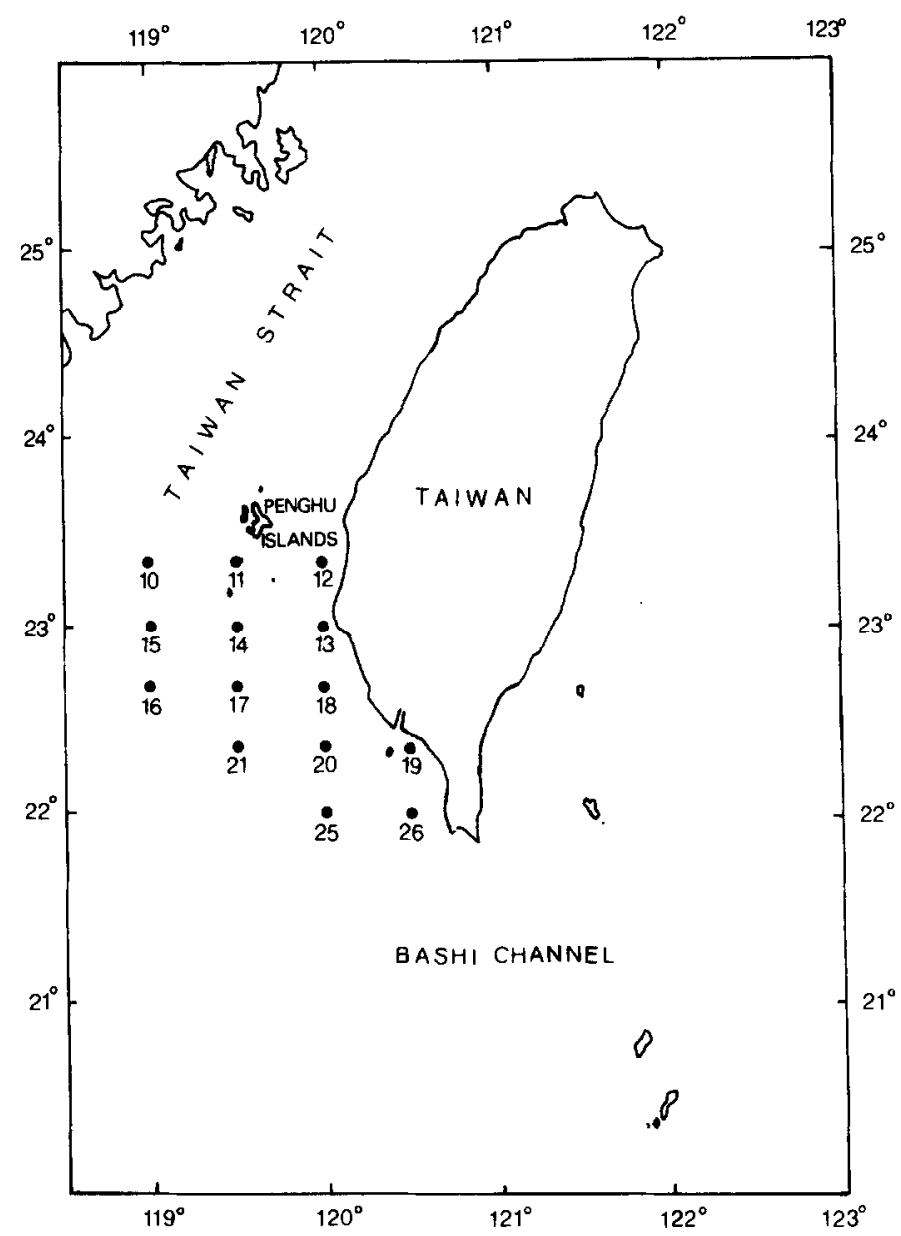

Figure 1. Map showing sampling locations in the southern Taiwan Strait.

branch of Kuroshio, also a warm current, passes through Bashi Channel and flows northward into the southern strait along the coast with relatively higher temperature and salinity. During autumn and winter this current encounters the southward flowing cold China Coastal Current in the vicinity of Penghu Islands and is then diverted southwestward into the South China Sea. Upwelling of deep water frequently occurs in late autumn and winter in the study area due to the interaction of waters flowing from opposite directions, the abrupt change of bottom topography, or the drift of surface water driven by strong north-east monsoon winds. Additionally, a large quantity of freshwater is discharged into the sea along the western coast, particularly in the rain and typhoon seasons from May to September. The consequent physical and chemical variability in those waters clearly influences the distribution patterns of marine organisms in the southern Taiwan Strait.

At the present time very little is known about phytoplankton in the southern Taiwan Strait. In a previous study the author investigated the seasonal standing crop and community structure of phytoplankton of this region (Huang, 1986), and in the present work particular attention has been given to the influence of hydrography on phytoplankton distribution using multivariate techniques. 
TABLE 1. Factor loadings on hydrographic parameters and cell densities in different months

\begin{tabular}{|c|c|c|c|c|}
\hline & August & October & December & May \\
\hline Factor $1\left({ }^{\circ}{ }_{0}\right)$ & $37 \cdot 2$ & $59 \cdot 9$ & $50 \cdot 3$ & $31 \cdot 8$ \\
\hline Depth & 0.749 & 0.774 & 0.421 & 0.366 \\
\hline Temperature & -0.014 & -0.891 & -0.964 & 0.224 \\
\hline Salinity & 0.569 & 0.893 & 0.855 & -0.181 \\
\hline pH & -0.263 & -0.242 & -0.874 & -0.613 \\
\hline Nitrite & 0.797 & -0.011 & -0.137 & 0.777 \\
\hline Nitrate & 0.855 & 0.926 & 0.683 & 0.931 \\
\hline Phosphate & 0.813 & 0.866 & 0.053 & $0 \cdot 178$ \\
\hline Silicate & -0.033 & 0.902 & 0.707 & 0.776 \\
\hline Log cells $1^{-1}$ & 0.052 & -0.161 & $-0 \cdot 145$ & -0.025 \\
\hline Factor $2\left({ }^{\circ}{ }_{0}\right)$ & $14 \cdot 7$ & $15 \cdot 1$ & $13 \cdot 8$ & $20 \cdot 2$ \\
\hline Depth & $-0 \cdot 341$ & -0.256 & $0 \cdot 161$ & -0.214 \\
\hline Temperature & 0.753 & 0.214 & -0.150 & 0.007 \\
\hline Salinity & -0.428 & $-0 \cdot 112$ & -0.065 & -0.742 \\
\hline $\mathrm{pH}$ & 0.029 & $0 \cdot 602$ & -0.094 & 0.489 \\
\hline Nitrite & 0.241 & 0.085 & 0.145 & -0.096 \\
\hline Nitrate & -0.005 & $-0 \cdot 070$ & $0 \cdot 227$ & $0 \cdot 148$ \\
\hline Phosphate & 0.023 & -0.133 & 0.918 & -0.252 \\
\hline Silicate & 0.012 & 0.501 & $-0 \cdot 244$ & 0.217 \\
\hline $\log$ cells $1^{-1}$ & 0.737 & 0.805 & 0.303 & 0.831 \\
\hline
\end{tabular}

\section{Materials and methods}

The locations of 14 sampling stations off the south-western coast of Taiwan are shown in Figure 1 Some or all were visited on four occasions during the cruises of Ocean Researcher I from August 1985 to May 1986. On each visit the temperature and salinity of the water were recorded using a CTD instrument before the water was sampled. The light transmittance in water was determined with both a Secchi disc and a Li-Cor 185 desk unit equipped with an underwater sensor. At each station waters at depths of 3, 10, 25, 50, 75 and $100 \mathrm{~m}$ to the surface were collected separately with Niskin samplers. For phytoplankton studies, 1-1 subsamples of water were preserved immediately after collection with Lugol's solution and stored in plastic bottles. The procedures of sample preparation and microscopic examination have been described previously (Huang, 1986). For nutrient study, water samples were stored at $5^{\circ} \mathrm{C}$ until they were analysed in the laboratory (not later than 10 days after collection). The detailed results of analysis have been reported in Hung et al. (1986), and these records of nutrient concentrations were used in the present study for comparison with phytoplankton data.

In the present study, statistical techniques were employed for both phytoplankton and hydrography data in order to simplify the complicated information and to allow easier interpretation of the variability within hydrographic and phytoplankton data. Factor analysis (Blackith \& Reyment, 1971; Jöreskog et al., 1976), a multivariate method of data reduction, is primarily used in the present study. In this analysis, all the relationships among variables are accounted for by relatively independent and interpretable, but nonobservable, factors. In order to simplify interpretation, it is common practice to rotate the factor axes after they have been established. The factor axes were rotated in an oblique process to a new position such that they best accorded with any distinct clusters of vectors 
TABLE 2. List of phytoplankton taxa in the study area

Bacillariophyceae

Achnanthes brevipes Agardh

A. longipes Agardh

Achnanthes sp.

Actinocyclus octonarius Ehrenberg

Actinocyclus sp.

Actinoptychus senarius Ehrenberg

A. splendens (Shad.) Ralfs ex Pritchard

Amphiprora alata (Ehrenb.) Kützing

A. gigantea var. sulcata (O'meara) Cleve

Amphiprora sp.

Amphora coffeaeiformis (Agardh) Kützing

A. costata W. Smith

A. cymbifera Gregory

A. lineolata Ehrenberg

A. ovalis Kützing

A. terroris Ehrenberg

Amphora sp.

Asterionella cleveanus Grunow

$A$. glacialis Castracane

Asterionella sp.

Asterolampra marylandica Ehrenberg

Asteromphalus heptactis (Bréb.) Ralfs ex Pritchard

Asteromphalus sp.

Bacillaria paxillifer (Mull.) Hendey

Bacteriastrum delicatulum Cleve

B. elongatum Cleve

B. hyalinum Lauder

B. hyalinum var. princeps (Castr.) Ikari

B. mediterraneum Pavillard

B. minus Karsten

$B$. varians Lauder

B. varians var. hispida (Castr.) Schroder

Biddulphia aurita (Lyngb.) Brébisson

B. granulata Roper

B. longicruris var. hyalina (Schrod.) Cupp

B. mobiliensis (Bail.) Grunow ex Van Heurck

B. obtusa (Kütz.) Ralfs

B. reticulum (Ehrenb.) Boyer

B. rhombus (Ehrenb.) W. Smith

B. sinensis Greville

B. tuomeyi (Bail.) Roper

Galoneis sp.

Cerataulina pelagica (Cleve) Hendey

Cerataulus smithii Ralfs ex Pritchard

Chaetoceros affine Lauder

C. atlanticum Cleve

C. atlanticum var. neapolitana (Schrod.) Hustedt

C. atlanticum var. skeleton (Schutt) Hustedt

C. breve Schutt

C. compressum Lauder

C. concavicorne Mangin

C. constrictum Gran

C. convolutum Castracane

C. curvisetum Cleve

C. decipiens Cleve

C. densum Cleve

C. didymum Ehrenberg

C. didymum var. anglica (Grun.) Gran
C. distans Cleve

C. diversum Cleve

C. indicum Karsten

C. janischianum Castracane

C. laciniosum Schutt

C. laevis Leuduger-Fortmorel

C. lauderi Ralfs

C. lorenzianum Grunow

C. messanense Castracane

C. muelleri Lemmermann

C. pelagicus Cleve

C. pendulus Karsten

C. peruvianum Brightwell

C. psetudocurvisetum Mangin

C. setoensis Ikari

C. subsecundum (Grun.) Hustedt

C. teres Cleve

Chaetoceros pl. sp.

Climacodium biconcavum Cleve

C. frauenfeldianum Grunow

Climacodium sp.

Climacosphenia moniligera Ehrenberg

Climacosphenia sp.

Cocconeis pediculus Ehrenberg

C. placentula Ehrenberg

C. scutellum Ehrenberg

Cocconeis sp.

Corethron criophylum Castracane

Coscinodiscus asteromphalus Ehrenberg

C. centralis Ehrenberg

C. concinnus W. Smith

C. gigas Ehrenberg

C. granii Gough

C. kützingii Schmidt

C. lineatus Ehrenberg

C. marginatus Ehrenberg

C. nitidus Gregory

C. nodulifera Janisch ex Schmidt

C. radiatus Ehrenberg

C. rothii (Ehrenb.) Grunow

C. subtilis Ehrenberg

C. wailesii Gran et Angst

Coscinodiscus pl. sp.

Cyclotella striata (Kütz.) Grunow

C. stylorum Brightwell

Cyclotella sp.

Cymbella affine Kützing

Dactyliosolen mediterraneus Peragallo

Diatoma hyalinum Kützing

Diatoma sp.

Diploneis bombus Ehrenberg

D. fusca (Greg.) Cleve

D. fusca var. hyperborea (Grun.) Hustedt

D. splendida (Greg.) Cleve

Diploneis sp.

Ditylum sol Grunow

Eucampia cornuta (Cleve) Grunow

E. zoodiacus Ehrenberg

Fragilaria oceanica Cleve

Fragilaria sp. 
TABLE 2. (Continued)

Gomphonema sp.

Gossleriella tropica Schutt

Grammatophora marina (Lyngb.) Kützing

Guinardia flaccida (Castra.) Peragallo

Gyrosigma balticum (Ehrenb.) Cleve

Gyrosigma sp.

Hemiaulus hauckii Grunow ex Van Heurck

H. sinensis Greville

Hemidiscus sp.

Hyalodiscus stelliger Bailey

H. subtilis Bailey

Lauderia borealis Gran

Leprocylindrus danicus Cleve

Licmophora abbreviata Agardh

Licmophora sp.

Lithodesmium undulatum Ehrenberg

Mastogloia sp.

Melosira distans (Ehrenb.) Kützing

M. jurgensii Agardh

M. moniliformis (Mull.) Agardh

M. nummuloides (Dillw.) Agardh

Melosira sp.

Navicula angusta Grunow

$N$. cancellata Donkin

N. clavata Gregory

N. directa (W.Sm.) Cleve

N. distans (W. Sm.) Cleve

$N$. forcipata Greville

$N$. humerosa Brébisson

$N$. lanceolata (Agardh) Kützing

$N$. membranacea Cleve

$N$. monilifera Cleve

$N$. perrhombus Hustedt

N. tuscula (Ehrenb.) Van Heurck

Navicula pl.sp.

Nitzschia acuminata (W. Sm.) Cleve

$N$. angularia W. Smith

$N$. closterium (Ehrenb.) W. Smith

$N$. delicatissima Cleve

N. fonticola Grunow

$N$. frustulum (Kütz.) Grunow

$N$. gracilis Hantzsch

$N$. hungarica Grunow

$N$. lanceolata W. Smith

$N$. littoralis Grunow

N. longissima (Bréb.) Ralfs ex Pritchard

$N$. longissima var. reversa Grunow

$N$. marginulata Grunow

$N$. marina Grunow

$N$. punduriformis Gregory

$N$. panduriformis var. intermedia Grunow

$N$. seriata Cleve

N. sigma (Kütz.) W. Smith

N. sigma var. intermedia W. Smith

N. spathulata Brébisson ex W. Smith

N. tryblionella Hantzsch

$N$. vitrea Norman

Nitzschia pl. sp.

Paralia sulcata (Ehrenb.) Cleve

Pirmularia sp.
Planktoniella sol (Wall.) Schut

Pleurosigma affine Grunow

$P$. angulatum var. strigosa (W. Sm.) Cleve

P. fasciola (Ehrenb.) W. Smith

$P$. intermedium W. Smith

$P$. naviculaceum Brébisson

P. normani Ralfs

$P$. pelagicum Peragallo

$P$. rigidum var. incurvata Grunow

P. strigosum W. Smith

Pleurosigma sp.

Podosira stelliger (Bail.) Mann

Rhabdonema adriaticum Kützing

$R$. arcuatum (Lyngb.) Kützing

Rhizosolenia acuminata (Perag.) Gran

$R$. alata Brightwell

$R$. bergonii Peragallo

$R$. castracanei Peragallo

$R$. crassispina Schroder

R. cylindrus Cleve

$R$. delicatula Cleve

$R$. fragilissima Bergon

$R$. hebetata Bailey

$R$. imbricata Brightwell

$R$. robusta Norman ex Pritchard

$R$. setigera Brightwell

$R$. stolterfothii Peragallo

$R$. styliformis Brightwell

$R$. styliformis var. latissima Brightwell

Rhizosolenia sp.

Schroederella delicatula (Perag.) Pavillard

Skeletonema costatum (Grev.) Cleve

Stauroneis amphioxys Gregory

Stephanopyxis nipponica Gran et Yendo

S. palmeriana (Grev.) Grunow

Stigmophira rostrata Wallich

Striatella unipunctata (Lyngb.) Agardh

Surirella amoricana Peragallo

S. fastuosa Ehrenberg

Surirella sp.

Synedra fasciculata (Agardh) Kützing

$S$.gaillonii (Bory) Ehrenberg

S. ulna (Nitzsch) Ehrenberg

S. ulna var. danica (Kütz.) Grunow

Synedra sp.

Thalassionema nitzschioides Hustedt

Thalassiosira baltica (Grun.) Ostenfeld

$T$. condensata Cleve

$T$. decipiens (Grun.) Jörgensen

T. eccentrica (Ehrenb.) Cleve

T. gravida Cleve

T. hyalina (Grun.) Gran

$T$. nordenskiold Cleve

$T$. pacifica Gran et Angst

$T$. rotula Meunier

Thalassiosira pl.sp.

Thalassiothrix frauenfeldii Grunow

T. longissima Cleve et Grunow

T. mediterranea var pacifica Cupp

Trachyneis aspera (Ehrenb.) Cleve 
TABLE 2. (Continued)

T. aspera var. elliptica Hendey

Triceratium favus Ehrenberg

T. formosum Brightwell

T. reticulum Ehrenberg

Triceratium sp.

Dinophyceae

Ceratium candelabrum (Ehrenb.) Stein

C. furca (Ehrenb.) Claparede et Lachmann

C. lineatum (Ehrenb.) Cleve

C. macroceros var. gallicum (Kof.) Jörgensen

C. massiliense (Gourr.) Jörgensen

C. pentagonum Gourret

C. teres Kofoid

Ceratium pl. sp.

Cladophyxis brachiolata Stein

Cochlodimium sp.

Dinophysis sp.

Glenodinium foliaceum Stein

Glenodinium sp.

Gonyaulax polygramma Stein

G. turbynei Murray et Whitting

Gymnodinium arcuatum Kofoid

G. ochraceum Kofoid et Swezy

G. rhomboides Schutt

$G$. sanquineum Hirasaka

G. vestifici Schutt

Gymnodinium sp.

Gyrodinium spirale (Bergh) Kofoid et Swezy

Noctiluca scintillans (Macartn.) Ehrenberg

Ornithocercus sp.

Oxytoxum gladiolus Stein

O. scolopax Stein

O. reticulatum (Stein) Butschi

O. tesselatum (Stein) Schutt

Oxytoxum sp.

Prorocentrum micans Ehrenberg

P. triangulatum Martin
P. triestinum Schiller

Protoperidinium abei (Abe) Paulsen

P. achromaticum (Lev.) Balech

$P$. balticum (Lev.) Lemmermann

$P$. cerasus (Pauls.) Balech

$P$. decipiens (Jorg.) Parke et Dodge

$P$. depressum (Bail.) Balech

P. faeoceros Paulsen

P.granii (Ost.) Balech

P. islandicum (Pauls.) Balech

P. marukawai Abe

P. oceanicum (Vanhoffen) Balech

$P$. pentagonum (Gran) Balech

P. pyriforme (Pauls.) Balech

P. subinerme (Pauls.) Loeblich III

P. thorianum (Pauls.) Balech

Protoperidinium sp.

Pyrocystis lunula Schutt

P. lanceolata Murray

P. noctiluca Murray

Scrippsiella trochoidea (Stein) Loeblich

Warnowia parva (Lohm.) Lindemann

Prymnesiaceae

Chrysachromulina sp.

Chrysophyceae

Dictyocha fibula Ehrenberg

Distephanus speculum (Ehrenb.) Hackel

Mesocena sp.

Cyanophyceae

Anabaena sp.

Pelagothrix clevei Schmidt

Richelia intracellularis Schmidt

Spirulina sp.

Trichodesmium contortum Wille

T. erythraeum Ehrenberg

T. thiebautii Gomont

representing variables (Harbaugh \& Merriam, 1968; Jöreskog et al., 1976). Because a large number of species occurred only occasionally and did not offer much useful ecological information, a criterion of selection of species was established before computation. A species selected for the analysis had a frequency of occurrence in greater than $15 \%$ of the total samples in the whole year's collections, irrespective of its abundance in particular samples. In addition, the variability caused by the absence of species included in the analysis was reduced by using logarithmic transformation of counting values (Estrada \& Blasco, 1979). That is $X \rightarrow \log (X+1)$, where $X$ is the number of a species in 11 of seawater. However, this transformation was not applied to hydrographic data. Multiple-regression and cluster analysis were also done on transformed data as an aid to the interpretation of phytoplankton distribution.

\section{Results and discussion}

Analysis of hydrographic data

Preliminary factor analysis based on 287 samples of entire collections yielded the first two most important factors, however, these factors did not explain as much variability as 


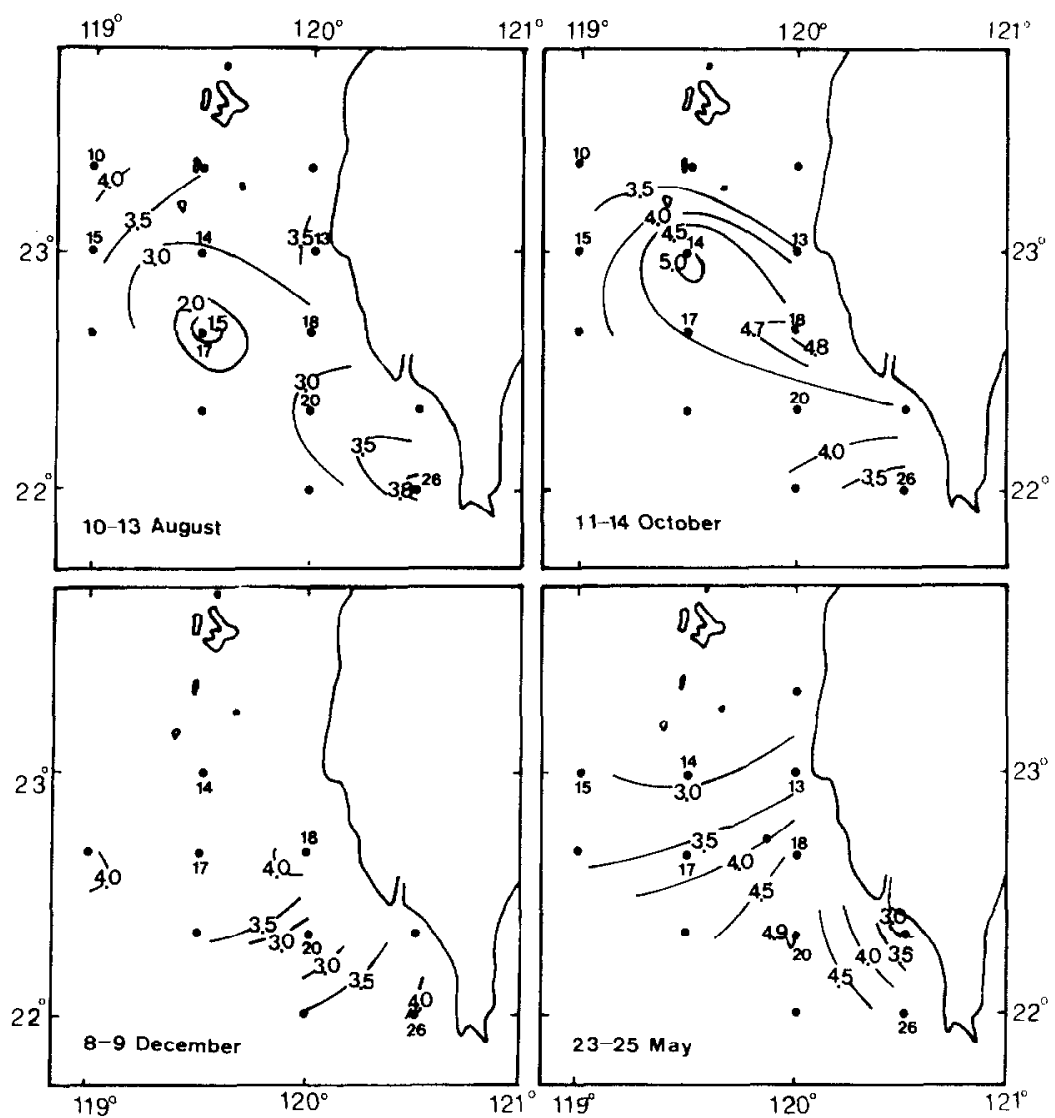

Figure 2. Distribution of blue-green algae in the top $25 \mathrm{~m}$ of the water (averaged log cell number $1^{-1}$ ).

expected, nor did the seasonal sequence of distribution. For this reason the subsequent factor analysis was done on the data collected on individual cruises (Table 1). Obviously, loadings on hydrographic parameters were variable with season. The first two factors explained more than $51{ }^{\circ}$ o f total variability. For factor 1 , the loading on temperature was extremely low in August because the whole strait water was occupied by northward flowing warm currents in summer (Chu, 1963; Fan, 1982). With October data, factor 1 accounted for $60_{\%}^{\circ}$ of total variability. This factor is referred to as the water-mass factor that can be deduced from high negative loading on temperature and positive loadings on salinity and nutrients. Furthermore, the high loading on depth suggested the stratification of waters in the study area. The result of the following Q-model factor analysis (Harbaugh \& Merriam, 1968; Klovan \& Imbrie, 1971; Jöreskog et al., 1976), correlating hydrographic environments in terms of the phytoplankton species composition which they possess, supports this phenomenon. However, the present factor analysis failed to demonstrate the variability explained by the high-temperature and high-salinity Kuroshio water. It could be that Kuroshio water gradually loses its characteristics as it enters the strait and mixes with other waters. The influence of water mass on the factor 1 became very evident during the winter period, yet the upwelling determined from $T-S$ and nutrient diagrams (Fan, 1982; Hung et al., 1986) was not detectable. The fact is that the upwelling was restricted to small areas and not comparable with other water movements in the 

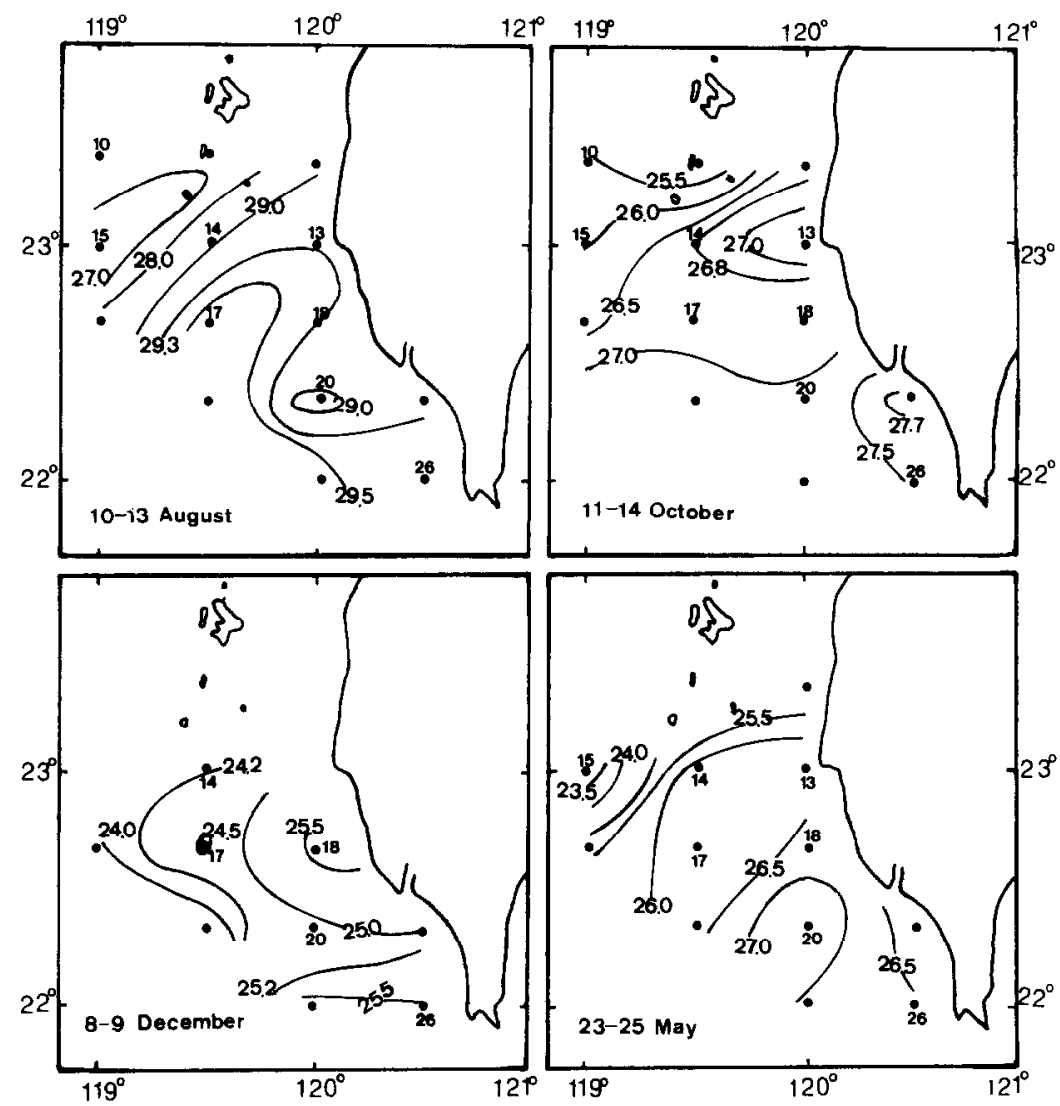

Figure 3. Distribution of temperatures in the top $25 \mathrm{~m}$ of the water $\left({ }^{\circ} \mathrm{C}\right)$.

whole study area. Correlation between upwelling and phytoplankton distribution has also been shown by Estrada and Blasco (1979), Blasco et al. (1980) and Estrada (1984) using principal-component analysis. In May, $\mathrm{pH}$ and nutrients, which relate to biological activity, accounted for the largest portion of the total variability.

Factor 2 accounted from $13 \cdot 8-20 \cdot 2 \%$ of the total variability (Table 1 ). This factor, except in December, was strongly influenced by algal activity represented mainly by the blue-green alga. Pelagothrix clevei in August and diatoms Thalassionema nitzchioides, Thalassiothrix frauenfeldii, Thalassiosira condensata, $T$. rotula and Bacteriastrum hyalinum in October. In May, high positive loading on algal density and negative loading on salinity indicated that the discharge of freshwater into the sea was important to algal distribution, particularly in the coastal area.

In the factor analysis, high loadings on both phytoplankton density and hydrographic parameters for the same factor do not necessarily mean that they were significantly correlated. In the present study their correlation was determined by multiple regression with the stepwise method at $p<0.05$ using the $F$-test. It appeared that temperature was the sole parameter influencing algal abundance in August, whilst both temperature and salinity were important to algal distribution in October and December. The spring outburst of phytoplankton was closely related to $\mathrm{pH}$, salinity, silicate, depth and nitrate. The above results agree with those of the previous factor analysis in the explanation of seasonal variations of hydrography and phytoplankton. 


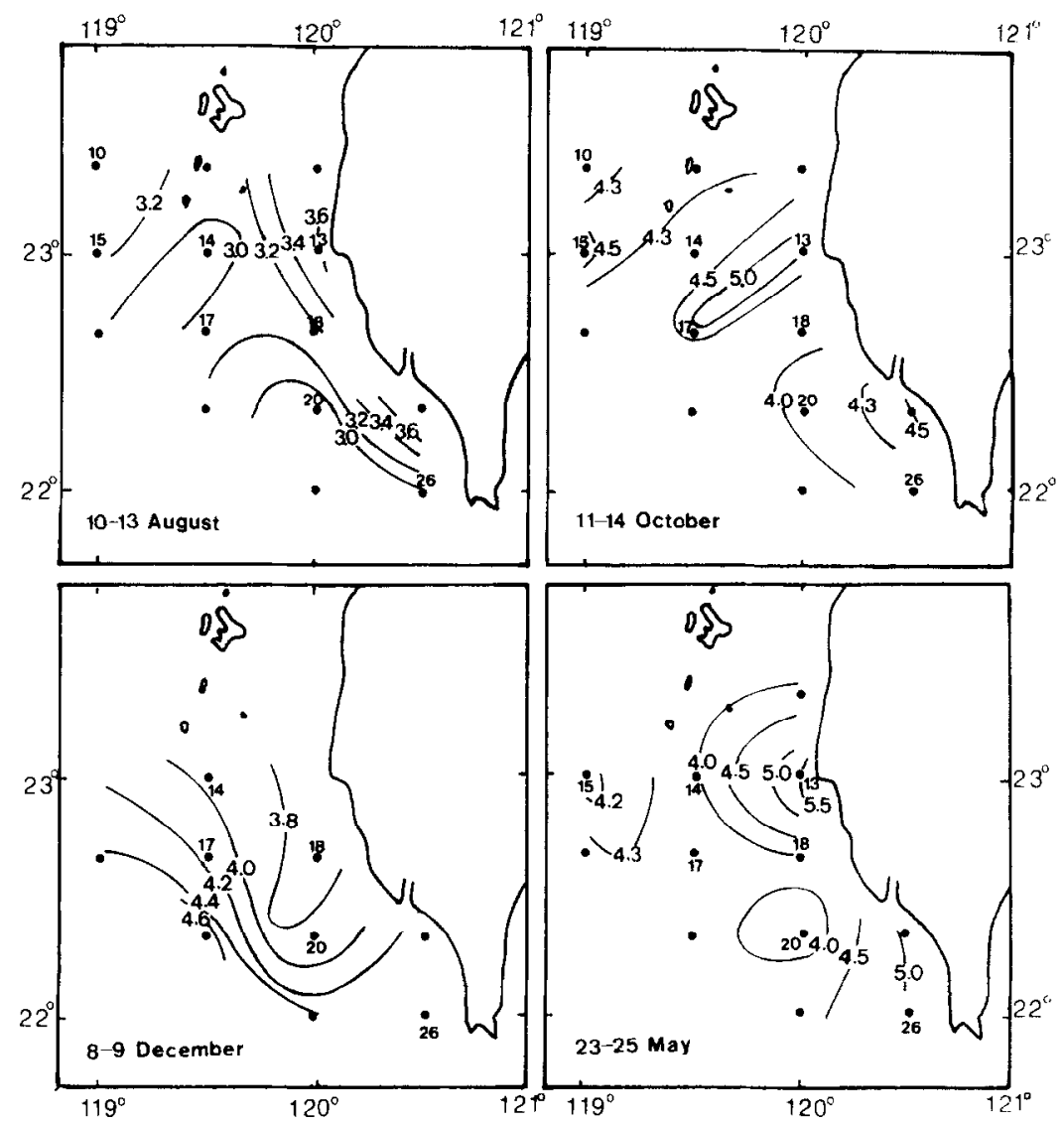

Figure 4. Distribution of diatoms and dinoflagellates in the top $25 \mathrm{~m}$ of the water (averaged $\log$ cell number $\mathrm{I}^{-1}$ ).

Phytoplankton assemblages in the study area

A total of more than 300 species and varieties of phytoplankton were obtained from the study area, of which 255 species were diatoms and 55 and seven species were dinoflagellates and blue-green algae, respectively (Table 2). The flora did not change significantly as compared with that in the previous year (Huang, 1986). A large number of species occurred in less than 15 of all samples and accounted for less than $20^{\circ} \%_{0}$ of all the standing crop in cell numbers. These rare species contributed very little ecological information to the present study. Whilst species of Bacteriastrum, Chaetoceros, Coscinodiscus and Thalassiosira, Thalassionema nitzschioides and Thalssiothrix frauenfeldii were the most abundant in the populations; they contributed from $5 \%$ to $15 \%$, of the total standing crops. In summer and autumn, higher standing crops of phytoplankton at some stations often represented a higher proportion of blue-green algae to diatoms and flagellates. The main blue-green algae were Pelagothrix clevei and Trichodesmium erythraeum. Very few dinoflagellates and other small flagellates were observed in the samples; most of them were Protoperidinium, Glenodinium and Ceratium.

Maximum standing crops of phytoplankton occurred in October and May due to the outgrowth of certain species of blue-green algae and diatoms. The majority of phytoplankton appeared in the water layer within $25 \mathrm{~m}$ of the surface. The light intensity at $25 \mathrm{~m}$ 
TABLE 3. Phytoplankton occurring in at least $15 \%$ of all samples; taxa selected for monthly factor analysis $(O$, October; $M$, May)

\begin{tabular}{|c|c|}
\hline 1. Achnanthes sp. (M) & 27. Nitzschia pl.sp. $(\mathrm{O}, \mathrm{M})$ \\
\hline 2. Amphora sp. & 28. Paralia sulcata \\
\hline 3. Bacillaria paxillifer & 29. Pleurosigma affine $(\mathrm{O})$ \\
\hline 4. Bacteriastrum hyalinum $(\mathrm{O}, \mathrm{M})$ & 30. Rhizosolenia alata $(\mathrm{M})$ \\
\hline 5. B. varians $(\mathrm{M})$ & 31. R. bergonii \\
\hline 6. Chaetoceros affine $(\mathrm{O})$ & 32. R. crassispina $(\mathrm{O}, \mathrm{M})$ \\
\hline 7. C. curvisetum $(\mathbf{M})$ & 33. R. imbricata $(\mathrm{O})$ \\
\hline 8. C. decipiens $(\mathrm{O})$ & 34. Skeletonema costatum $(\mathbf{M})$ \\
\hline 9. C. lorenzianum $(\mathbf{O}, \mathbf{M})$ & 35. Synedra sp. (M) \\
\hline 10. C. messanense & 36. Thalassionema nitzschioides $(\mathrm{O}, \mathrm{M})$ \\
\hline 11. Chaetoceros pl. sp. $(\mathrm{O}, \mathrm{M})$ & 37. Thalassiosira baltica \\
\hline 12. Coscinodiscus lineatus $(\mathrm{O})$ & 38. T. condensata $(\mathrm{O}, \mathrm{M})$ \\
\hline 13. Coscinodiscus pl. sp. $(\mathbf{O}, \mathbf{M})$ & 39. T. decipiens \\
\hline 14. Diploneis sp. & 40. T.gravida $(\mathrm{O})$ \\
\hline 15. Eucampia cornuta & 41. T. hyalina $(\mathrm{O})$ \\
\hline 16. E. zoodiacus & 42. T. pacifica $(\mathrm{O})$ \\
\hline 17. Fragilaria ocenica $(\mathrm{O})$ & 43. T. rotula $(\mathrm{O}, \mathrm{M})$ \\
\hline 18. Hemiaulus hauckii $(\mathrm{O}, \mathrm{M})$ & 44. Thalassiosira pl. sp. $(\mathrm{O}, \mathrm{M})$ \\
\hline 19. Lauderia borealis (M) & 45. Thalassiothrix frauenfeldii $(\mathrm{O}, \mathrm{M})$ \\
\hline 20. Melosira sp. & 46. Triceratium sp. $(\mathbf{M})$ \\
\hline 21. Navicula pl. sp. $(\mathrm{O}, \mathrm{M})$ & 47. Dictyocha fibula $(\mathrm{O}, \mathrm{M})$ \\
\hline 22. Nitzschia closterium $(\mathrm{O})$ & 48. Distephanus speculum $(\mathrm{M})$ \\
\hline 23. N. longissima & 49. Glenodinium sp. \\
\hline 24. N.panduriformis $(\mathrm{M})$ & 50. Pelagothrix clevei $(\mathrm{O}, \mathrm{M})$ \\
\hline 25. N. seriata $(\mathrm{O}, \mathrm{M})$ & 51. Trichodesmium thiebautii $(\mathrm{O}, \mathrm{M})$ \\
\hline 26. N. sigma & \\
\hline
\end{tabular}

of most sampling stations decreased less than $10 \%$ of the incident light at the surface. Therefore, algal densities in the upper $25 \mathrm{~m}$ were used to illustrate the distribution pattern of phytoplankton. From Figure 2 it can be seen that blue-green algae and diatoms appeared in the north-westward direction off the south-west coast of Taiwan which is consistent with the movement of the Kuroshio and South China Sea currents (Figure 3). Maximum amounts were found at station 14 in October and at station 20 in May, respectively. The close relationship between temperature and blue-green alga distribution has been indicated previously (Huang, 1986). Figure 4 shows that both diatoms and dinoflagellates were abundant at stations $13,14,15,17$ and 26 in these two months. In December, the cold water moved down from the north as shown in Chu (1963), Fan (1982) and Figure 3, and so most phytoplankton occurred southward of and near station 25. During the summer period the phytoplankton were relatively homogenous in the study region.

\section{Analysis of phytoplankton data}

From the whole year's collections, 51 taxa (Table 3) were selected for both factor and cluster analyses. These species occurred in at least $15 \%$ of all samples (287), regardless of their abundance. In the preliminary results of the factor analysis based on the entire data most species which were dominant throughout the year did not contribute significantly to the variability; therefore, they reduced the seasonal variation. In order to avoid the multimonth variability as shown in Estrada (1984), and to facilitate interpretation, the subsequent factor analysis was based on each of the monthly collections. Twenty-seven taxonomic groups (Table 3) selected from October and May assemblages were included in 


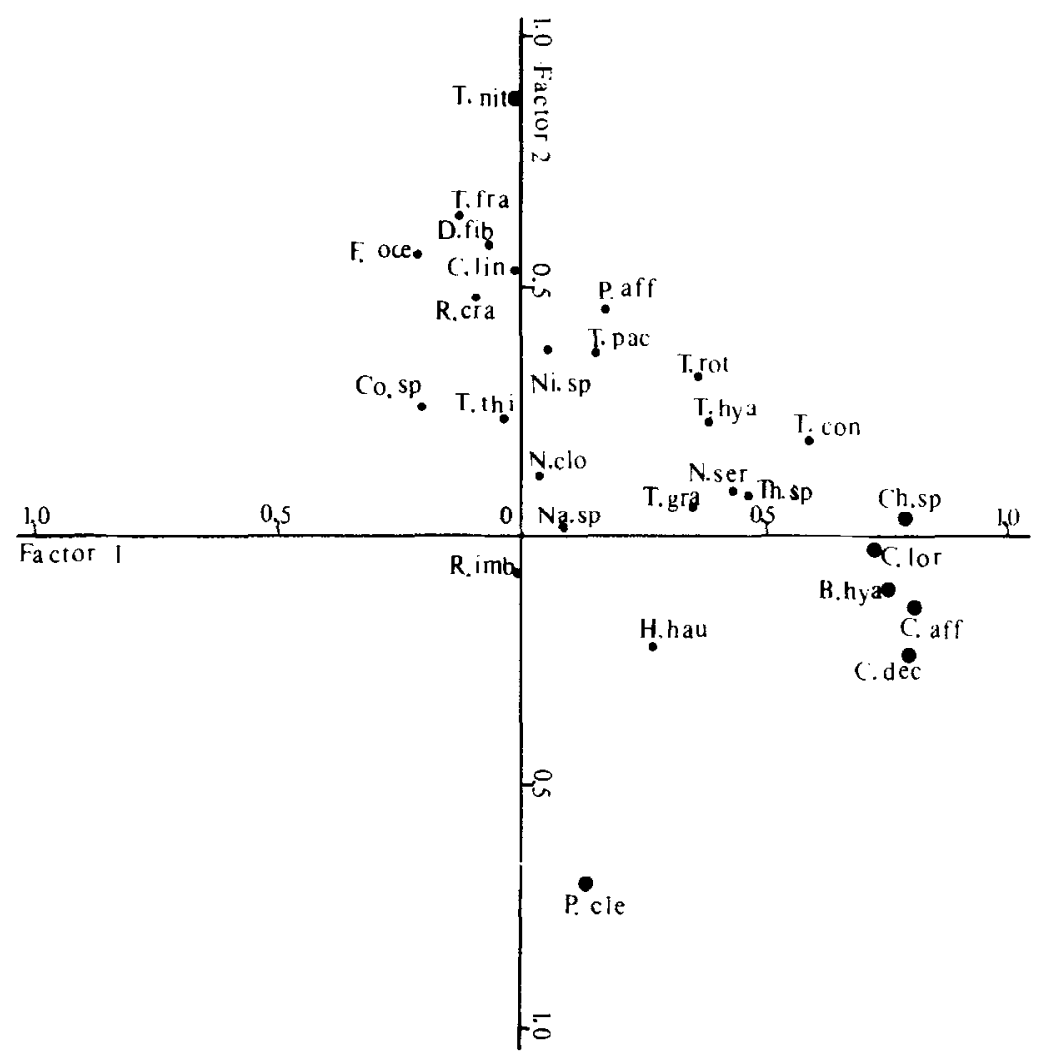

Figure 5. The positions of 27 species vectors on the first two factors produced from October assemblages. Abbreviations refer to the species names in Table 3.

the analysis. These species occurred in at least $20^{\circ}{ }_{0}$ of all samples taken on each cruise. Figure 5 clearly shows three clusters of species strongly influencing the first two axes in October. Chaetoceros affine together with C. decipens, C. lorenzianum, Chaetoceros sp. and Bacteriastrum hyalinum, form a cluster and accounted for the major portion of the total variability of factor 1. Examination of the basic data showed that these taxa were plentiful in observed assemblages, especially at station 13. Thalassionema nitzschioides, which was abundant in the offshore area of stations 15 and 16 , formed the second cluster and strongly influenced factor 2 . The third cluster was occupied by Pelagothrix clevei only in the negative side of factor 2 ; this is an alga which predominated at station 14 . The rest of the species contributed rclatively less variability to the first two factors. With May data (Figure 6) Nitzschia seriata, Skeletonema costatum, Chaetoceros lorenzianum, Thalassiosira condensata and Lauderia borealis strongly influenced factor 1, and Thalassiothrix frauenfeldii, Thalassionema nitzschioides and Chaetoceros curvisetum influenced factor 2 in opposite directions. These diatoms were dominant at station 12, 13, 19 and 26. Blue-green algae explained the lower May variability, although they were abundant at station 20 . The above results revealed seasonal and spatial variations of the main taxa. Nevertheless, in multivariate analysis phytoplankton species which have high loadings in the same cluster may not necessarily occur together frequently (Maddock et al., 1981). Therefore, interpretation of the results of the analysis must be made with caution.

The geographic pattern of phytoplankton distribution can be detected when seasonal variation is removed from the multivariate analysis (Matta \& Marshall, 1984). In the 


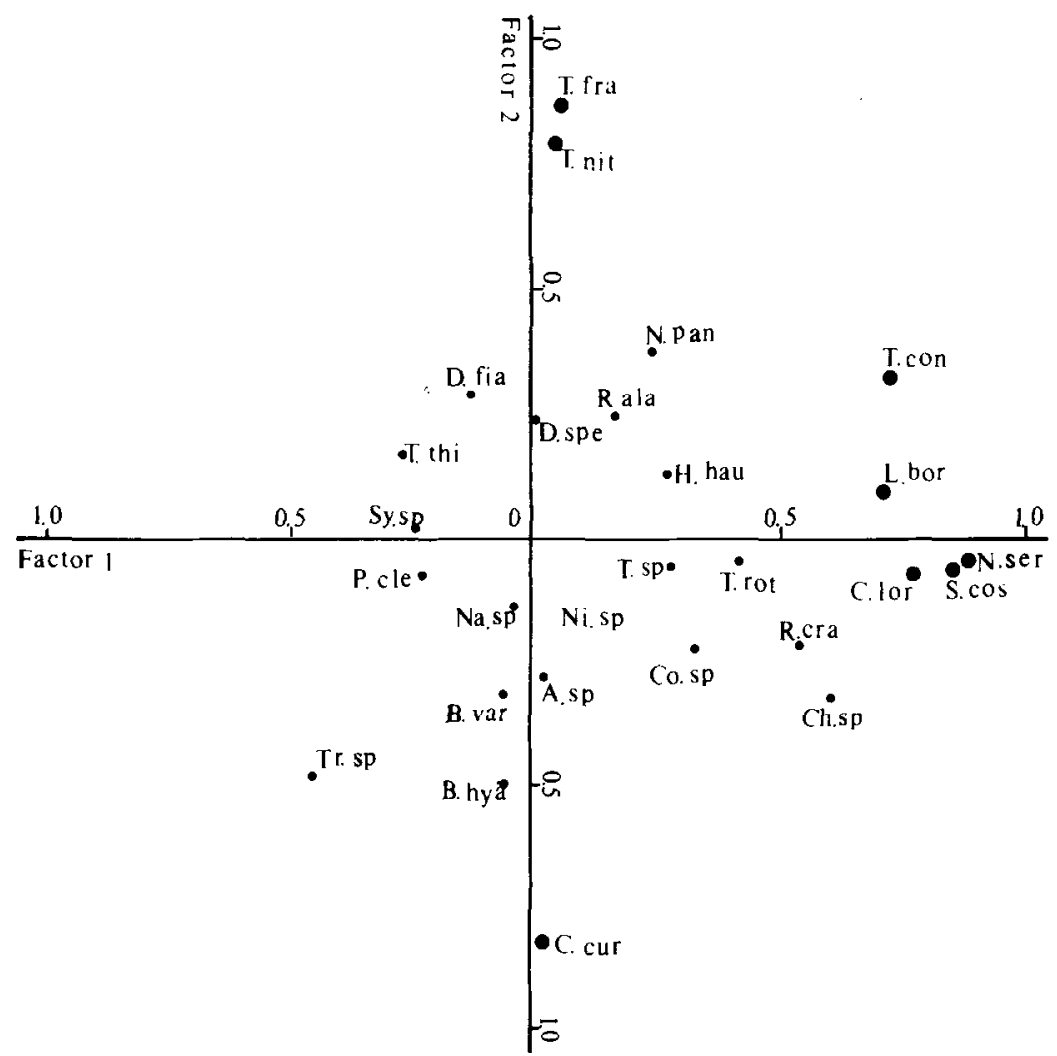

Figure 6. The positions of 27 species vectors on the first two factors produced from May assemblages. Abbreviations refer to the species names in Table 3.

TABLE 4. Loadings of the first factor on sampling stations and depths in October and May

\begin{tabular}{|c|c|c|c|c|c|c|}
\hline \multirow{3}{*}{$\begin{array}{c}\text { Station } \\
\text { No. }\end{array}$} & \multicolumn{6}{|c|}{ Depth $(\mathrm{m})$} \\
\hline & \multicolumn{3}{|c|}{ October 1985} & \multicolumn{3}{|c|}{ May 1986} \\
\hline & 3 & 10 & 25 & 3 & 10 & 25 \\
\hline 10 & 0.125 & 0.116 & 0.092 & - & - & - \\
\hline 11 & $0 \cdot 113$ & $0 \cdot 028$ & $0 \cdot 088$ & - & - & - \\
\hline 12 & 0.666 & 0.422 & 0.607 & $-0 \cdot 108$ & $0 \cdot 327$ & -0.048 \\
\hline 13 & 0.777 & 0.766 & 0.847 & -0.089 & -0.071 & 0.135 \\
\hline 14 & 0.833 & 0.924 & $0 \cdot 847$ & 0.362 & $0 \cdot 290$ & 0.843 \\
\hline 15 & 0.079 & 0.185 & 0.656 & -0.043 & -0.182 & 0.069 \\
\hline 16 & 0.710 & 0.873 & 0.757 & 0.141 & $0 \cdot 183$ & 0.657 \\
\hline 17 & 0.223 & $0 \cdot 299$ & 0.607 & 0.730 & 0.618 & 0.825 \\
\hline 18 & 0.850 & 0.722 & -0.068 & 0.791 & 0.947 & 0.891 \\
\hline 19 & -0.133 & $-0 \cdot 141$ & 0.095 & 0.046 & 0.027 & -0.110 \\
\hline 20 & 0.345 & -0.083 & 0.688 & 0.922 & 0.943 & 0.944 \\
\hline 21 & 0.512 & 0.840 & 0.908 & 0.945 & 0.767 & 0.941 \\
\hline 25 & -0.048 & 0.822 & $0 \cdot 144$ & 0.833 & 0.882 & 0.942 \\
\hline 26 & $0 \cdot 190$ & 0.398 & 0.342 & 0.481 & 0.522 & 0.214 \\
\hline
\end{tabular}




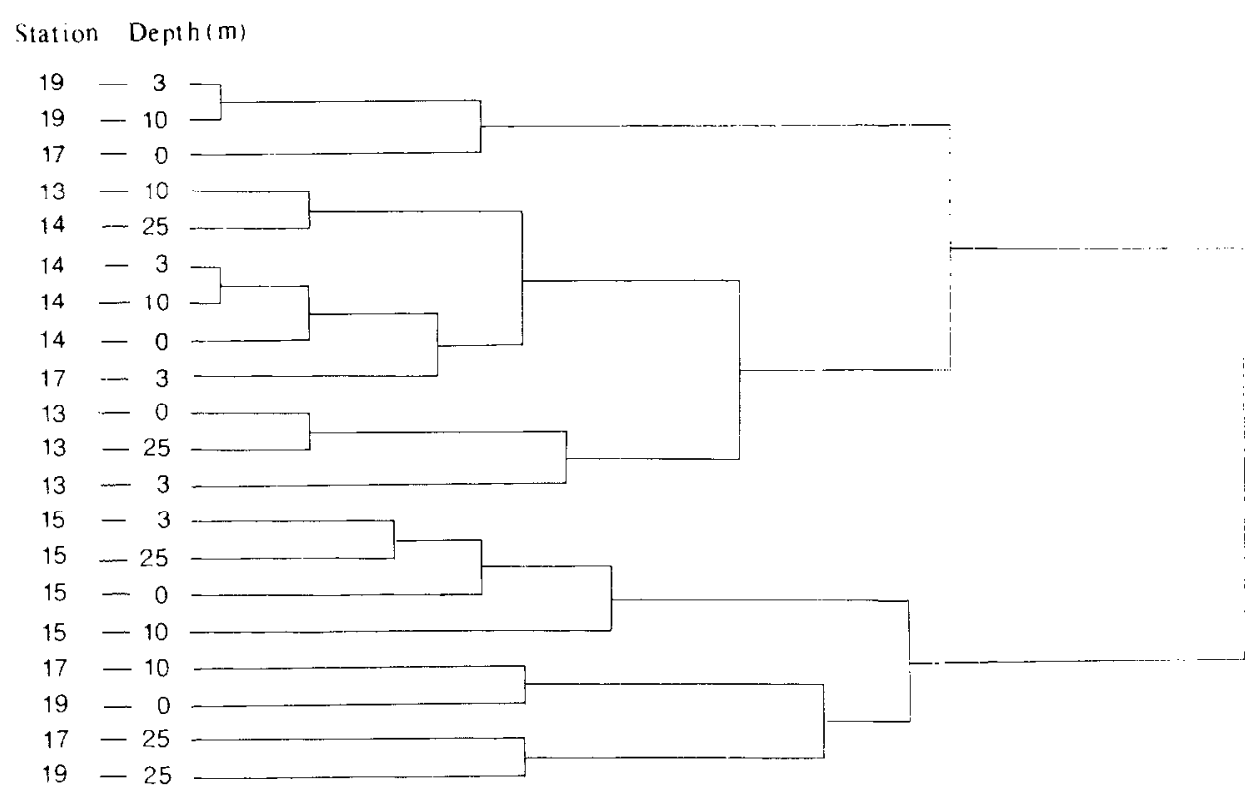

Figure 7. Dendrogram showing clusters of phytoplankton populations collected from different depths at five stations in October 1985.

Q-model analysis, based on 51 taxonomic groups, the variabilities explained by locations were evidently different. It appears that stations 13, 14, 16 and 21 had higher cell densities (Figure 4) and, therefore, contributed a larger portion of variability to factor 1 in October, whilst stations 20,21, 25, 17 and 18 accounted for the variability in May (Table 4). According to the species composition of assemblages, the former can be referred to as the diatom factor and the latter as the blue-green alga factor. In addition, highly variable loadings with depths were also found in some small areas, for example at stations 18 and 25 in October and at stations 14 and 16 in May. It is of particular interest that loadings at 3 and $10 \mathrm{~m}$ at station 18 were very high, but negligible at $25 \mathrm{~m}$ in October. This was probably related to the upwelling of deep water to the subsurface layer (the temperature at $25 \mathrm{~m}$ was more than $2^{\circ} \mathrm{C}$ lower than at the surface) as shown in Hung et al. (1986). Therefore, the vertical variability of the phytoplankton population can reflect stratification or vertical movement of water in certain areas.

The close relationship between the species composition of phytoplankton and water movement has been shown previously (Estrada \& Blasco, 1979; Estrada, 1984). The similarity between two algal populations can be determined on the basis of the species present. Thus it can be assumed that the higher the similarity between two phytoplankton populations, the closer the characteristics of the two water regimes. Because of the very complicated hydrography in October, phytoplankton populations at five major stations in that month were examined by grouping into clusters based on 51 taxonomic groups (Table 3 ). The results of both the factor and the cluster analyses were quite similar. As shown in the dendrogram of cluster analysis (Figure 7), four clusters appeared in the last three large distances. Populations at stations 13 and 14 combined into a cluster, while those at station. 15 in the offshore area formed an isolated cluster. The first cluster appeared in the hightemperature regime $\left(27.0 \pm 0.3^{\circ} \mathrm{C}\right)$ that was possibly a mixture of Kuroshio and local coastal waters, and the second cluster in the colder regime $\left(25 \cdot 8 \pm 0 \cdot 1^{\mathrm{T}} \mathrm{C}\right)$ under the 
influence of the southward flowing China Coastal Current. Examination of the species composition of clusters also showed different major taxa. Separate clustering of stations 17 and 19 at both ends of the dendrogram was attributed to the discontinuity of water movement, which again resulted from the upwelling near two stations as mentioned above.

It is concluded that multivariate analysis provides ecologically significant information in the interpretation of phytoplankton distribution under the influence of hydrography. Vertical, spatial and temporal variabilities of small-scale data (monthly collections) were apparent in the present study. The above results show that the distribution of different phytoplankton populations can be a useful tracer of water movement.

\section{Acknowledgements}

Thanks are due to the crew of $R / V$ Ocean Researcher $I$ for their kind assistance during the cruises and to Mr Chang J. H. and Miss Cheng C. Y. for microscopic examination and data analysis. I am greatly indebted to Dr Hung T. C. for his kindness in providing me with nutrient data. This study was financially supported by the National Science Council of the Republic of China.

\section{References}

Blackith, R. E. \& Reyment, R. A. 1971 Multivariate Morphometrics. Academic Press, London.

Blasco, D., Estrada, M. \& Jones, B. 1980 Relationship between the phytoplankton distribution and composition and the hydrography in the northwest African upwelling region near Cabo Corbeiro. Deep-Sea Research 27A, 799-821.

Chu, T. Y. 1963 The oceanography of the surrounding waters of Taiwan. Report of the Institute of Fishery Biology of the Ministry of Economic Affairs and National Taizuan University 1, 29-39.

Estrada, M. 1984 Phytoplankton distribution and composition off the coast of Galicia (northwest of Spain). Fournal of Plankton Research 6, 417-434.

Estrada, M. \& Blasco, D. 1979 Two phases of the phytoplankton community in the Baja California upwelling. Limnology and Oceanography 24, 1065-1080.

Fan, K. L. 1982 A study of water masses in Taiwan Strait. Acta Oceanographica Taiwanica 13, 140-153.

Harbaugh, J. W. \& Merriam, D. F. 1968 Computer Applications in Stratigraphic Analysis. Wiley, London.

Holligan, P. M., Maddock, L. \& Dodge, J. D. 1980 The distribution of dinoflagellates around the British Isles in July 1977: a multivariate analysis. Fournal of the Marine Biological Association of the United Kingdom 60, 851-867.

Huang, R. 1986 Phytoplankton distribution off the southwestern coast of Taiwan. Acta Oceanographica Taiwanica 16, 103-116.

Hung, T. C., Tsai, C. C. H. \& Chen, N. C. 1986 Chemical and biomass studies: (1) Evidence of upwelling off the southwestern coast of Taiwan. Acta Oceanographica Taiwanica 17, 29-44.

Jöreskog, K. G., Klovan, J. E. \& Reyment, R. A. 1976 Geological Factor Analysis. Elsevier Scientific Publishing Company, Amsterdam.

Klovan, J. E. \& Imbrie, J. 1971 An algorithm and FORTRAN IV program for large-scale Q-Inode factor analysis. Mathematical Geology 3, 61-67.

Maddock, L., Boalch, G. \& Harbour, D. S. 1981 Populations of phytoplankton in the western English Channel between 1964 and 1974. Fournal of the Marine Biological Association of the United Kingdom 61, $565-583$.

Matta, J. F. \& Marshall, H. G. 1984 A multivariate analysis of phytoplankton assemblages in the western North Atlantic. Fournal of Plankton Research 6, 663-675.

Moll, R. A. \& Rohlf, F. J. 1984 Analysis of temporal and spatial phytoplankton variability in a Long Island salt marsh. Journal of Experimental Marine Biology and Ecology 51, 133-144. 